\section{'Early St. Ann': A New Early Maturing Satsuma Mandarin}

\author{
W.J. Bourgeois ${ }^{1}$, R.J. Constantin ${ }^{2}$, and M.J. Falcon ${ }^{3}$ \\ Lousiana State University AgCenter, Citrus Research Station, Louisiana \\ Agricultural Experiment Station, 22193 Highway 23, Port Sulphur, \\ LA 70083
}

Additional index words. citrus, cultivar development, satsuma mandarin, Citrus unshiu

'Early St. Ann’ (Fig. 1), a new early maturing satsuma mandarin cultivar (Citrus unshiu Marcovitch), is the product of the Louisiana State Univ. (LSU) AgCenter's citrus research program. The objective of the program is to develop fresh-market lines of citrus fruits (navels, satsuma, and other cultivars) with improved quality, fruit characteristics, and production (Bourgeois et al., 1993; 1995; Brown et al., 1976; Reuther et al., 1967). 'Early St. Ann', field tested as 'LA333 ', is an improved quality, early maturing satsuma mandarin that ripens in early September to mid-October.

\section{Origin}

'Early St. Ann' is an open-pollinated cultivar of unknown satsuma mandarin parentage. It was selected in the 1980s from early work on seedlings planted in the late $1960 \mathrm{~s}$ by the late Ralph Brown, the first superintendent of the Citrus Research Station of LSU.

\section{Description}

Fruit characteristics. 'Early St. Ann' produces typical satsuma, oblate-shaped fruit that are medium to large in size and greater in yield per tree and average fruit weight than that of the cultivar 'Early Armstrong' (Table 1). Fruit diameter is also larger than that of 'Early Armstrong' (Table 1). 'Early St. Ann' has light yellow, thin leathery skin with an attractive appearance. Rind adherence is slight to moderate, but it has the easy peel of a satsuma mandarin. Fruit puffiness ranges from none to slight. Flesh color is orange and more intense than that of 'Early Armstrong'. Flesh is tender, with easily separated segments. Fruit is considered seedless, but may have an occasional seed. Taste and flavor are excellent-slightly acid, juicy, and an improvement over that of 'Early Armstrong'.

Foliage characteristics. The leaves of 'Early St. Ann' are dark green, large (7.6$10.2 \mathrm{~cm}$ long and $2.5-7.6 \mathrm{~cm}$ wide), lanceolate, tapering at the base and apex and

\footnotetext{
Received for publication 1 May 2001. Accepted for publication 19 Nov. 2001. Approved for publication by the Director of the Louisiana Agricultural Experiment Station as manuscript No. 01-82-0211. ${ }^{1}$ Professor.

${ }^{2}$ Professor and Resident Director.

${ }^{3}$ Former Research Associate.
}

have a thin petiole.

Tree characteristics. 'Early St. Ann' trees are medium in size but slightly larger than 'Early Armstrong' and very productive. Growth pattern is typical of the satsuma
Fig. 1. ‘Early St. Ann' satsuma. 1992 at Port Sulphur, La.

${ }^{2}$ Yield: Represents means of 4 reps at 2 trees/scion/rootstock/plot.

${ }^{y}$ Fruit weight: Average of five fruit/plot (4 reps). (4 reps). C32 = Citrange C32. mandarin in that it is spreading with drooping, thornless branches. Fruit buds and blossom sets are heavy and evenly distributed throughout the tree. Fruit matures early and attain the required Louisiana commercial standard solids : acid ratio of 10:1 for legal sale early in the season (Table 2). The maturity range for 'Early St. Ann' indicates that harvest can begin in early September and continue through mid-October slightly ahead of 'Early Armstrong' (Table 3).

\section{Recommendations}

'Early St. Ann' has performed well for several years in experimental trials at the Citrus Research Station in Louisiana. This cultivar is intended to complement the early marketing of improved quality early satsuma mandarins and not to replace existing

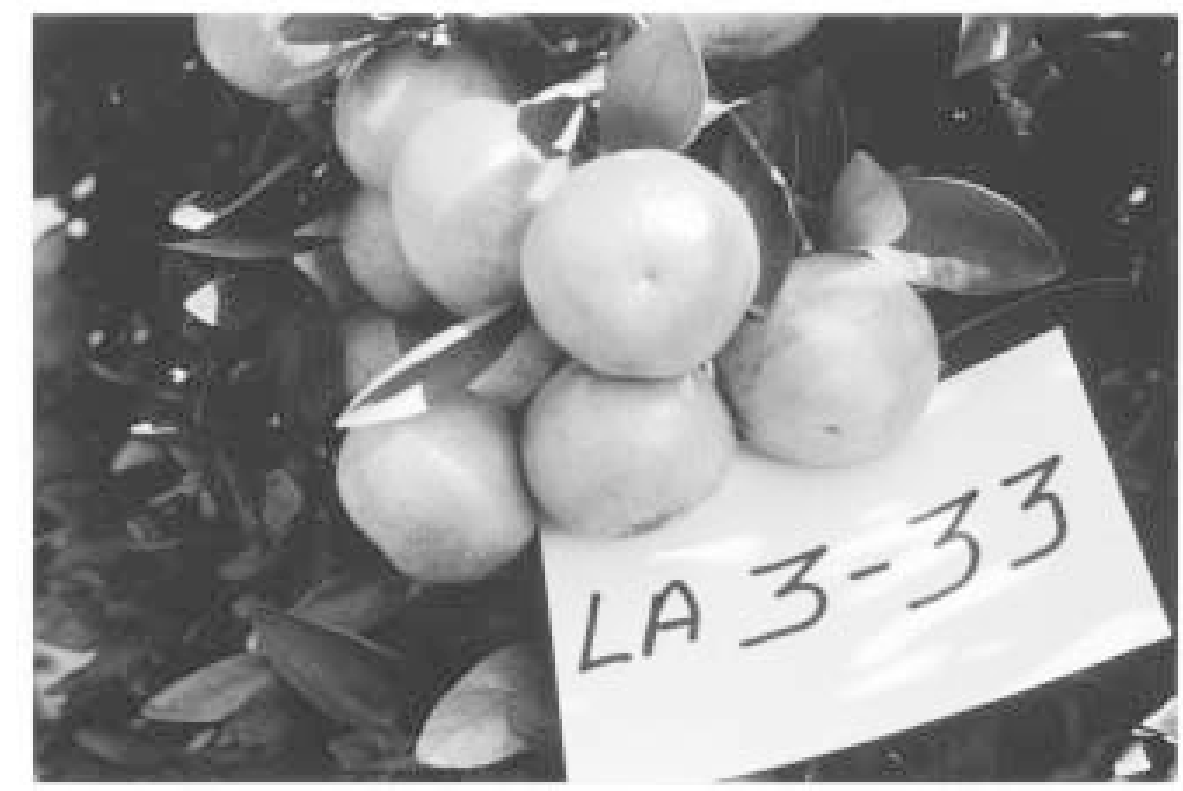

Table 1. Average yield and fruit quality of early maturing satsuma cultivars from 1993-2000. Planted: Apr.

\begin{tabular}{|c|c|c|c|c|c|c|c|c|}
\hline Cultivar & $\begin{array}{c}\text { Yield }^{z} \\
\text { (kg/tree) }\end{array}$ & $\begin{array}{l}\text { Fruit wt } t^{y} \\
(\mathrm{~g})\end{array}$ & $\begin{array}{c}\text { Fruit } \\
\text { diam }^{\mathrm{x}} \\
(\mathrm{cm})\end{array}$ & $\begin{array}{c}\text { Rind } \\
\text { thickness }{ }^{w} \\
(\mathrm{~mm})\end{array}$ & $\begin{array}{c}\text { Juice } \\
\mathrm{pH}\end{array}$ & $\begin{array}{c}\text { Juice } \\
(\%)\end{array}$ & $\begin{array}{c}\text { Soluble } \\
\text { solids }^{v} \\
(\%)\end{array}$ & $\begin{array}{c}\text { Solids : acid } \\
\text { ratio }^{\mathrm{u}}\end{array}$ \\
\hline Early Armstrong-R ${ }^{\mathrm{t}}$ & $41.3 c^{s}$ & $153.3 \mathrm{~b}$ & $7.14 \mathrm{~b}$ & $2.57 \mathrm{ab}$ & $4.2 \mathrm{a}$ & $41.5 \mathrm{ab}$ & $6.9 \mathrm{~b}$ & $12.8 \mathrm{c}$ \\
\hline Early St. Ann-R & $62.8 \mathrm{~b}$ & $164.3 \mathrm{a}$ & $7.34 \mathrm{ab}$ & $2.55 \mathrm{ab}$ & $4.4 \mathrm{a}$ & $40.4 \mathrm{ab}$ & $7.3 \mathrm{ab}$ & $15.0 \mathrm{a}$ \\
\hline Early St. Ann-S & $89.9 \mathrm{a}$ & $170.5 \mathrm{a}$ & $7.54 \mathrm{a}$ & $2.78 \mathrm{a}$ & $4.4 \mathrm{a}$ & $40.2 \mathrm{ab}$ & $7.2 \mathrm{ab}$ & $14.1 \mathrm{ab}$ \\
\hline Early St. Ann-C35 & $94.7 \mathrm{a}$ & $162.5 \mathrm{a}$ & $7.47 \mathrm{ab}$ & $2.52 \mathrm{ab}$ & $4.4 \mathrm{a}$ & $43.9 \mathrm{a}$ & $7.2 \mathrm{ab}$ & $14.1 \mathrm{ab}$ \\
\hline Early St. Ann-C32 & $91.3 \mathrm{a}$ & $166.5 \mathrm{a}$ & $7.47 \mathrm{ab}$ & $2.61 \mathrm{ab}$ & $4.3 \mathrm{a}$ & $37.9 \mathrm{~b}$ & $6.9 \mathrm{~b}$ & $13.9 \mathrm{~b}$ \\
\hline
\end{tabular}

${ }^{x}$ Fruit diameter: Measuring by placing a caliper over the apex of five fruit/plot (4 reps).

"Rind thickness: Measuring with caliper the rind of five fruit/plot that has been horizontally cross-sectioned

'Soluble solids: Determined by applying blended juice of five fruit/plot to a hand held brix refractometer. "Solids acid ratio: Titration of juice sample with $0.1 \mathrm{~N} \mathrm{NaOH}$ to determine titratable acid then calculating the solids : acid ratio using the following $\mathrm{S} / \mathrm{A}=$ soluble solids divided by titratable acid.

'Letter refers to rootstock upon which trees were budded: $\mathrm{R}=$ Rubidoux; $\mathrm{S}=$ Swingle; $\mathrm{C} 35$ = Citrange C35;

${ }^{s}$ Means followed by the same letter are not significantly different (Duncans multiple range test, $P=0.05$ ). 
Table 2. Soluble solids and solids : acid ratio as fruit maturity indicators of early satsuma cultivars for two seasons at Port Sulphur, La.

\begin{tabular}{|c|c|c|c|c|}
\hline \multirow[b]{3}{*}{ Cultivar } & \multicolumn{4}{|c|}{ Maturity evaluation factors } \\
\hline & \multicolumn{2}{|c|}{ Soluble solids (\%) } & \multicolumn{2}{|c|}{ Solids : acid ratio } \\
\hline & $\overline{9 / 24 / 99}$ & $9 / 8 / 00$ & $9 / 24 / 99$ & $9 / 8 / 00$ \\
\hline$\overline{\text { Early Armstrong-R }}{ }^{z}$ & 7.5 & 7.5 & 9.7 & 8.9 \\
\hline Early St. Ann-R & 8.5 & 9.0 & 14.4 & 13.0 \\
\hline
\end{tabular}

${ }^{2}$ Letter refers to the rootstock upon which trees were budded: $\mathrm{R}=$ 'Rubidoux'.

cultivars. Several factors that warrant attention in the production of this cultivar are: 1) fruit susceptibility to brown rot (Phytophthora citrophthora) just prior to harvest which will require control measures such as copper compounds or other suitable fungicides; 2) the leaf-footed plant bug (Leptoglossus phyllopus) is attracted to the fruit of this cultivar, thus scouting and monitoring are necessary to time sprays for its control; and 3) heavy fruit set can occur, resulting in reduced individual fruit size. 'Early St. Ann' has performed well on various rootstocks such as Poncirus trifoliata 'Rubidoux,' Swingle citrumelo, and Citranges C35 and C32. 'Early St. Ann' is recommended for commercial and home planting of early market satsumas in Louisiana's citrus growing areas.

\section{Availability}

Limited quantities of budwood will be available from the LSU AgCenter Citrus Research Station, 22193 Highway 23, Port Sulphur, LA 70083.
Table 3. Fruit maturity range of satsuma cultivars at Port Sulphur, La.

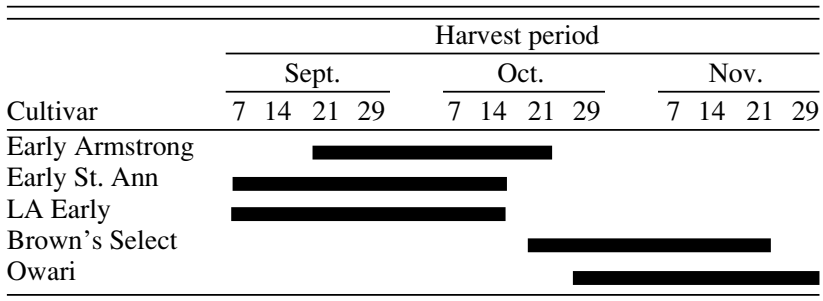

Literature Cited

Bourgeois, W.J., R.J. Constantin, and A.J. Adams. 1993. 'Brown's Select': A new mid season satsuma cultivar. LSU Agr. Ctr., Louisiana Agr. Expt. Sta. Circ. No. 133

Bourgeois, W.J., R.J. Constantin, and A.J. Adams. 1995. 'Brown's Select': A new midseason satsuma cultivar. HortScience 30:391-392.

Brown, R.T., P.L. Hawthorne, J.E. Love, D.W. Newsom, and T.J. Raiford. 1976. Kimbrough: A new cold hardy satsuma variety. LSU Agr. Ctr., Louisiana Agr. Expt. Sta. Circ. No. 102.

Reuther, W., H.J. Webber, and L.D. Batchelor. 1967. The citrus industry, history, world distribution, botany and varieties. Volume 1 . Univ. of Calif. 